\title{
Remodelling a changing language of tourism: from monologue to dialogue and trialogue ${ }^{1}$
}

\author{
Graham M. S. Dann ${ }^{i}$ \\ Finnmark University College (Norway)
}

\begin{abstract}
When the "language of tourism" was initially articulated, tourism formed part of the modernist project, wherein its unilateral, monological discourse was framed within the parameters of social control. However, there is evidence today that it has now been transformed on account of the digitalised communication of the Internet. Indeed, there is currently a more egalitarian, postmodern ethos of dialogue, or even trialogue, between the key players of tourism: the industry, the tourist and the touree. Consequently, a new heuristic framework becomes necessary, one that reflects the changes that are rapidly occurring. With examples, a cell-by-cell approach is adopted in three constituent models which together illustrate a shifting paradigm in terms of the media that are now open to greater democratisation.
\end{abstract}

Keywords: language of tourism; monologue; modernism; dialogue; trialogue; (re)modelling

Título: El cambiante lenguaje del turismo: del monólogo al diálogo y al triálogo

Resumen: Cuando empezó a desarrollarse el "lenguaje del turismo", el turismo formaba parte del proyecto "modernista", cuyo discurso unilateral y monológico había surgido bajo parámetros de control social. En la actualidad, sin embargo, tenemos pruebas de que este discurso ha sufrido una transformación, debido a la difusión de la comunicación digital en Internet. En efecto, existe hoy un espíritu "postmoderno", más igualitario, abierto al diálogo e incluso al "triálogo" entre los principales interlocutores del turismo: la industria del turismo, el turista y la comunidad receptora. Por esta razón, resulta necesaria una nueva perspectiva heurística, que refleje los cambios en tan rápida evolución. A continuación, se abordará un análisis sistemático de tres modelos constitutivos, que ilustran conjuntamente el paradigma cambiante de los medios de comunicación, hoy abiertos a la mayor democratización.

Palabras clave: lenguaje del turismo, monólogo, modernismo, diálogo, triálogo, remodelación

\footnotetext{
i E-mail: dann_graham@yahoo.co.uk
} 
Introduction: Changes that have occurred within tourism and the societies from which it is generated

At the time when The Language of Tourism first appeared in the mid-1990s (Dann, 1996) much of the West, whence the majority of international tourism originated, was still under the political influence of a prevailing modernist ideology. Whether they were Republican or Democrat, Conservative or Labour, Christian Democrat or Communist, many of these tourism-generating societies were rationally organised along managerial lines. Statistical targets were typically set for health, education, the economy, and so on, to the extent that almost every facet of human existence became centralised under the overarching power of the State or, in the case of the European Union, the Super-state. In spite of the corresponding lip service rhetoric of a "me too" individualism associated with Thatcherism and Reaganomics, and a few cosmetic changes in partisan thinking, such a top-down monological situation, though arguably to a lesser extent, in some respects still continues today.

Tourism, too, tended to be structured in a similar modernist fashion by defining it as an industry in the form of self-fulfilling prophecy. Following its initial emergence in the wake of the supreme rationalist project of the Industrial Revolution, it became a logical escape valve for workers who were transported to preselected locations by trains travelling in straight lines as the shortest distance between two points. It was thus no coincidence to find Thomas Cook appearing at this juncture as the first provider of factory- to-wholesome destination-and-back excursions for the proletariat (Brendon, 1991). Nor was it surprising to discover that his underpinning modernist ideology continued with the same evangelical fervour as a logo-centric legacy (Wang, 2000) for over a century in the package tour, holiday camp and Club Méditerranée under the believed, though unsubstantiated pretext of a greater democratisation of tourism. Block bookings, charter flights, standardised all-inclusive resorts, McDonaldization (Ritzer, 1993) and Disneyfication (Fjellman, 1992) constituted the order of the day, and their orders were in turn issued by tour operators and their uniformed holiday representatives.

Under such a quasi-dictatorial, total institutional system, mass tourism proliferated, and with it came its own version of monological communication (Dann, 2001a). Here there was a unilateral, unidirectional conveying of messages from a typically anonymous transmitter, thought to possess a monopoly on truth, to a correspondingly faceless and homogeneous public, through a variety of publicity vehicles at every stage of the vacation experience (pre-trip, on-trip and post-trip). There was precious little turn taking or turn signalling, (as would be evident in a discussion or telephone conversation, for example), hardly any feedback, and scant interaction between sender and receiver. It was thus an asymmetrical process in which an often unidentified persuader provided selective information for viewers or listeners cast in the passive mode of persons with enviable wants, (rather than needs). The largely promotional text was an euphoric, ideologically laden, cliché ridden discourse (Dann, 2001b), whose prophetic utterances became tautologically fulfilled. Just as touristic interactions could be considered as associations of distrust between persons of wealth encountering individuals with knowledge (van den Berghe, 1994), once a third player entered the scene - the tourism industry - both power and affluence became concentrated in its hands. It was no doubt for this reason that Hollinshead and Jamal (2001: 64) spoke of tourism as bolstering "restrictive, monological and heavily capitalised worldviews which tend[ed] to help concretise pseudo-colonialist, urban-industrial and pungently North-Atlantic / Judaeo-Christian certitudes upon alterity." Whatever the medium, whether written, auditory, visual, or a combination of all three, the same monological quality was in evidence. Depending on the channel, one party wrote, spoke or performed; the other respectively read, listened or observed. In those days, the ex cathedra pronouncements of the tourism industry were imparted from on high without fear of challenge, safe in the knowledge that there was a negligible chance of the addressee answering back.

However, there are now many signs on the horizon that such a monological situation has begun to change, if indeed it has not already been partially transformed and sociologically theorised (Denzin, 1986). The modernist project, while still mainly the preserve of target-driven politicians and dictators, has given way to a postmodern ethos of the people that rejects authoritarianism and rigid scientific distinctions based ideologically on capitalist, positivist, functionalist and consensual hierarchies of class, gender and age, as many a despot has recently learnt to his cost in such countries as Egypt and Libya, for instance. In this new topsy-turvy, de-differentiated world of the age of the image, the simulacrum has transformed reality into hyper-reality (Baudrillard, 1983) and the recent language sciences and games of postmodern communication of the media (Lyotard, 1984) have undermined the tyranny of the earlier meta-narrative of the natural sciences speaking as an infallible, predictable discourse that promised illusory freedom and unity of knowledge. Here the distinction between the developing or developed world becomes fuzzy as the modern "other" becomes a postmodern "ex-primitive" (MacCannell, 1992). Here also the previous verticality of knowledge is being, or has been, substituted by horizontal egalitarianism, and the proverbial (hu)-man-in-the-street is at last able to have his or her say. This replacing of political voicelessness with voice has now reached the world of info-entertainment. In the UK, for example, the BBC television consumer programme, Watchdog, has been broadcasting for over 30 years, and elsewhere on that network there are now, more than ever, greater opportunities for on-air viewer and citizen journalist, image-filled, blog-like reactions to the unbalanced, pseudo-professional coverage of television news (e.g., Newswatch) as well as the exposure of bias in drama 
and documentary programmes (e.g., Points of View), with simultaneous responses from producers to their critics.

Within the last fifteen years, and thanks to the advent of the Internet, this electronic medium of worldwide communication has ensured that it has become a key location for the pleas of consumers to be heard. Companies, in turn, have the opportunity of responding to their dissatisfied clients, and the latter can provide additional feedback as to how their complaints have been addressed. All this verbal to-ing and fro-ing is moreover conducted in the public domain, so that those similarly afflicted can join in the discussion with accounts of their own related experiences.

As regards tourism and how it is handled by television can be gauged from the previously mentioned Watchdog programme. Here issues are often taken up on behalf of vacationers and those responsible (e.g., tour operators, airlines) are confronted on a live show about the non-fulfilment of their promises. Typically, matters such as the inadequate pitch of plane seats, the misrepresentation of a hotel by a brochure, unanticipated construction work at a resort, food poisoning, etc. are highlighted. Often these vignettes of disappointment and frustration are accompanied by consumer video and mobile phone coverage of the alleged service failures with voiceovers by the aggrieved parties. TV holiday shows, too, incorporate some of this Schadenfreude material into their popular transmissions, again using video footage supplied by the customer. Indeed, tourists are positively encouraged to take camcorders, cameras and mobile phones with them on their trips, (sometimes the equipment is supplied by the television station), if only to provide photographic evidence of their disenchantment.

In relation to the Internet, and for the past decade and a half (Buhalis and Law, 2008), there have been several avenues for word-of-mouth to assume the digital features of "Word-of-Web" (or perhaps, more appropriately, "wordof-mouse"). Here the voice of satisfaction ("word-of-wish") can be registered, as also that of dissatisfaction ("word-ofwhinge"). The channels for such communication are also quite varied, ranging from e-guidebooks (e.g., the chatrooms and travel forums provided by the likes of Lonely Planet $(2004,2011)$ and Rough Guides $(2004,2011)$ ) to general (e.g., Planet Feedback (2011) ("complaint", "compliment" "question", "suggestion" of most consumer areas, but also inclusive of hotels, resorts, airlines, airports, travel agencies and cruise lines) and Complain Domain (2011) (featuring 19 countries and 7 online solicitors), or specific (e.g., Holiday Travel Watch (2011) (with guidelines on how to "prepare" (pre-trip), "take action" (ontrip) and "resolve" (post-trip), as well as "Crow's Nest" for complaints, "Calling Card" to obtain assistance while overseas and "Ceeviews" with comments), Holiday Complaints (2011) (dealing with initiated complaints; free initial advice and thereafter legal drafting in order to obtain "breakthroughs"), complaint sites that implicitly or explicitly include holidays in their list of grudges.

There are additionally plenty of online locations that feature travel diaries or travel "blogs", (a subset of frequently updated accounts, e.g., business blogs, political blogs), wherein individuals with similar interests can communicate with one another (Dann and Liebman Parrinello, 2007). In this instance, the "travel(bl)og" is a sort of amateur, interpersonal e-travelogue using such sites as My Trip Journal (2011), (to capture memories, explore the world, plot journeys, post stories, with maps and photos), Travel Pod (2011) (the Web's original travelblog with "quick links" to destinations, guided tours, playing traveller IQ challenge and exchanging tips in forums; as well as "partners", e.g., cheap flights, cruise reviews and tips on travel with children), and I GoUGo (2011) (with over 1 million reviews and photos and 3 million+ world travellers, relating to destinations, hotels, photos and over 1 million points of interest). However, perhaps the most influential of all these sites is Trip Advisor (2011) (which helps people "plan the perfect trip" by identifying flights, restaurants, things to do, cruises, holiday rentals, photos and forums). The last all important category relates to destinations, along with accommodation and restaurants, as well as to air travel, cruises, family travel, timeshares, outdoor travel, and other Trip Advisor causes. This no holds barred site, (which attracts some 40 million users per month to its website, thereby making it "the largest and most powerful travel guide in the world" (Channel 4, 2011), can make many an hotelier extremely nervous and occasionally quite ill, on account of its candid evaluations and reviews, which, like its print media counterpart, can promote or demote. Since all these interactive channels provide collective evidence of the greater democratisation of the language of tourism, surely the time is now ripe for providing updated models that incorporate the change from one-way to two-way and three-way communication between the tourist industry, the tourist and the touree, (the last term being coined by van den Berghe (1994).

At this point, it should also be mentioned that, just as such a framework can help fill a theoretical void, so too can it establish an agenda for future empirical investigations. Indeed, it can act as a storehouse for the growing evidence which supports the contention that the adequate responses of businesses, (including travel companies), to customer grievances can achieve higher levels of satisfaction than if there were no complaint in the first place (e.g., Tyrell / Woods, 2004). It can also encourage contributions to domains where there is otherwise little research, and extend related inquiries to areas where even less attention has been paid (Lee / Hu, 2004; Schoefer / Enew, 2004; Shea / Enghagen / Khullar, 2004). Here one thinks of the vast amounts of unanalysed emails, digital photographs and text messages that tourists send to one another or which they transmit to potential tourists in the form of friends and relatives.

However, and in spite of the impressive gains made through online communication, it is still a two tier system with haves and have not's. Due to such inequalities as differences in access, broadband speed and expense, there is inevitably a "digital divide" that roughly follows the 
contours of centre and periphery (Minghetti and Buhalis, 2010) and, in some cases, social class.

\section{Remodelling the language of tourism}

\section{Model 1: The language of tourism as monologue}

In order to become aware of these opportunities for exploring dialogue and trialogue in "the language of tourism", as also to establish their theoretical underpinning, it is necessary to provide a consecutive series of three models that encapsulates the transition from monologue to more open forms of communication.

It can be seen from table 1 that here there are nine instances of monological communication. They are predicated on three types of participants addressing themselves and each other singly, without response or significant feedback. Hence the direction of such messages is topdown from sender (arranged horizontally) to addressee (positioned vertically). Examples of each type of discourse contained in the nine possible cells are intended as illustrations that are not claimed to be either exhaustive or comprehensive. A brief cell-by-cell commentary follows, one that describes the various situations. The limitations of each implicitly suggest a potential for change.

Cell 1 is where the industry talks to itself. An instance of this type of discourse is in-house training. Here the emphasis is on information and how facts are passed down from management gurus having the necessary knowledge and experience to novices lacking such essential requirements. Teaching and research programmes standardized by the likes of the World Tourism Organisation and designed for tourism students at the graduate and under- graduate levels would also fall into this category. An example of the industry addressing tourees in a similar monological fashion (cell 7) is the a priori survey. Here a checklist of industry identified, close-ended questions is imposed on respondents without giving them the a posteriori opportunity to reply in their own open-ended, selfdefined terms (ipsissima verba) to issues that they, rather than the researchers, consider to be important.

However, it is cell 4, (where the industry speaks to tourists), that comprises the most familiar and frequent occurrences of monologue. Here the traditional media of "the language of tourism" are employed, (i.e., print, audio and visual media, either singly or in combination), without any feedback from the targeted audience. Brochures, for example, direct verbal and pictorial messages to potential tourists - images that are predominantly supply-driven and featuring the pull factor attributes of destinations selected by tour operators. Such one-way communication, (that can also be found in advertisements, travelogues, videos, etc.), is facilitated by other allied properties of "the language of tourism" - tautology, euphoria, sender anonymity and the assumption of receiver homogeneity (Dann, 1996). All such monologue forms part-and-parcel of the modernist project.

An example of tourist-industry monological communication (cell 2) lies in the domain of non-publicised complaints where visitors vent their feelings orally upon tourism personnel working in various sectors of the industry ranging from transportation to entertainment and hospitality, without allowing significant response to remedy the situation. Replies to hotel guest questionnaires, where there is no industry feedback to the visitor, rep-
Table 1: The Language of Tourism as Monologue

\begin{tabular}{|c|c|c|c|}
\hline & $E$ & $\mathrm{~N}$ & $\mathrm{R}$ \\
\hline ADDRESSEE & INDUSTRY & TOURISTS & TOUREES \\
\hline INDUSTRY & $\begin{array}{l}\text { (1) } \\
\text { In-house training sessions; } \\
\text { Standardized tourism degree } \\
\text { programmes }\end{array}$ & $\begin{array}{l}\text { (2) } \\
\text { Complaints; } \\
\text { Guest questionnaires; } \\
\text { Servqual inquiries }\end{array}$ & $\begin{array}{l}\text { (3) } \\
\text { Local newspapers } \\
\text { and magazines; } \\
\text { Local radio and } \\
\text { television }\end{array}$ \\
\hline TOURISTS & $\begin{array}{l}\text { (4) } \\
\text { Traditional media of the } \\
\text { language of } \\
\text { tourism: } \\
\text { e.g., brochures, } \\
\text { guidebooks, } \\
\text { travelogues }\end{array}$ & $\begin{array}{l}\text { (5) } \\
\text { Lectures; } \\
\text { Slide shows }\end{array}$ & $\begin{array}{l}\text { (6) } \\
\text { Unofficial notices; } \\
\text { Graffiti }\end{array}$ \\
\hline TOUREES & $\begin{array}{l}\text { (7) } \\
\text { A priori surveys }\end{array}$ & $\begin{array}{l}\text { (8) } \\
\text { Orders }\end{array}$ & $\begin{array}{l}\text { (9) } \\
\text { Instructions }\end{array}$ \\
\hline
\end{tabular}

resent the written analogue to this type of unilateral communication, as are the responses to those "servqual" (service quality) inquiries (Weiermair and Fuchs, 1999) that purport to measure differences between expectation and reality without doing anything sufficient to remedy the resulting dissatisfaction. Here, even though the initiative has been taken by the industry, attention focuses on the unheeded discourse of the consumer.

Monological tourist-totourist messages (cell 5) are more in evidence when the addressee is a potential tourist, ready to be persuaded by the authoritative discourse of the sender (actual tourist). Persons who attend the lectures of returning travellers, (in the tradition of those Victorian audiences who listened in po- 
lite silence to the exploits of imperial explorers sponsored by prestigious scientific societies), illustrate the situation, as do their contemporary equivalents who attend the uninterrupted slideshows of their unchallenged, though knowledgeable and experienced, friends and relatives, thereby allowing the latter to gain status points at the expense of the former. Of course, these types of communication may not be entirely monological, particularly where their imaginative speakers encourage debate. However, if they are structured more formally in the framework of a prepared or even spontaneous question and answer session, the direction of communication is still vertical from sender to addressee without much opportunity for the latter to participate.

Cell 8, tourist-touree monologue, is typified by tourists issuing orders to members of the host population. Here such asymmetrical communication depends on an assumed role of super-ordination in the tourist and a corresponding imputed role of sub-ordination in the touree, which together indicate expected compliance from the latter. Where the host also forms part of the tourism industry, this type of communication is of the cell 2 variety, (cf. Mayo and Jarvis, 1981 for an example of a belligerent hotel guest shouting commands at a bar tender). Only where it extends to residents more generally, is it of the cell 8 variety.

Turning to touree-initiated monologue, cell 3 comprises those cases where the visited address the industry. Typical media for such communication are the local press and radio call-in programmes, particularly where members of the host society are well educated and articulate and where their informed observations are frequently met with disdainful sullen silence from the tourism authorities.

Cell 6 relates to touree-tourist monologue. An example of such communication is the unofficial notice. This is a written, and sometimes illustrated message that does not necessarily emanate from the industry (cf. Dann, 2003), but rather from members of the host community. Like tourism notices (cell 4), however, it can range from a simple request, for example, "please do not park in front of these gates" to a more threatening order, (e.g., "penalty for improper use $£ 1,000$ ), the main difference being that the implied sanction of the former lacks the authority of the latter. Graffiti also constitute an instance of toureetourist monologue, where typically a message denotes extremely unwelcome attitudes towards visitors (e.g., 'Yankees, go home!'). Yet of this rarely studied unobtrusive measure, it is difficult to think of any cases where tourists have answered back (Kilroy, 1983) by inscribing their own "writings on the wall" as similarly insulting counter-messages. That is why the nature of this type of communication is essentially monological.

Finally, cell 9 relates to touree-touree monologue. Here an example is the unidirectional instructions that residents leave for one another as they go about their daily lives. Like the unofficial notices of cell 6 , these messages do not have the official backing of the industry.

\section{Model 2: The language of tourism as dialogue}

Here in model 2 (Table 2) it is evident that the major difference between dialogue and monologue is that the three key players of the industry, tourist and touree, instead of being considered separately and solely as either senders or addressees, are now regarded as combining both roles, if not simultaneously, then at least consecutively. As a result, and because it is not always possible to identify the initiator of the communication, it means that, in table 2 , three of the former nine cells from table 1 are reiterated, i.e., cells 2,3 and 6 respectively repeat information contained in cells 4,7 and 8 . For that reason, illustrative examples and commentary are correspondingly reduced.

First there are the instances of internal dialogue - the industry, tourists and tourees communicating as both sender and addressee among themselves.

In cell 1 , where message and response are limited to the industry, increased egalitarianism can lead to conversations among equals, as in the brainstorming associated with advertising campaigns, the designing of logos, branding exercises and discussions of the results of customer surveys. True, there has been relatively little academic research of such dialogue, (apart from occasional mentions in such texts as Morgan and Pritchard, (2000)), but missed opportunities do not render the topic any less important.

When it comes, in cell 5, to tourists "talking" to fellow tourists (e.g., via e-mails, "blogs", word-of-mouth), it is important to acknowledge that the sort of dialogue that takes place between equals can occur in any of the following stages of a holiday:

- Pre-trip: potential tourists consult actual tourists who have already experienced a given destination. A good example would be Cruises. Co. UK (2011). According to its website, with approximately 21,000 members in its "all aboard" forum, future passengers can get in touch with persons going on the same ship as themselves as well as compare notes about previous voyages.

- On-trip: actual tourists communicate with fellow travellers; such tourists speak to friends and relatives back home, e.g., by sending digital photos, e-mails and text messages. The recipients, in turn, can become potential or actual tourists, or, in cases where the messages are indicative of dissatisfaction, may be dissuaded from travelling to a particular place.

- Post-trip: actual tourists give accounts of their experiences to friends and relatives (cf., on-trip above).

There is thus a constant dialogue across the three timeframes, a process that is as iterative and circular as the phenomenon of tourism itself. To the channels of communication previously identified from cells 2 and 4, can be added inter alia the contents of conversations (word-of-mouth). A sub-set of the latter comprises "overheards", picked up by "systematic lurking" (Dann, Nash and Pearce, 1988: 28) and often on location. There are also confessions, more intimate one-to-one conversations that 
Table 2: The Language of Tourism as Dialogue. Model 2: The language of tourism as dialogue.

\begin{tabular}{|c|c|c|c|}
\hline & $S E N D E R$ & \multicolumn{2}{|c|}{$A D D R E S S E E$} \\
\hline $\begin{array}{l}\text { SENDER AND } \\
\text { ADDRESSEE }\end{array}$ & INDUSTRY & TOURIST & TOUREE \\
\hline INDUSTRY & $\begin{array}{l}\text { (1) } \\
\text { Advertising/ } \\
\text { Brain storming; } \\
\text { In-house discussion } \\
\text { of analysed data }\end{array}$ & $\begin{array}{l}(2) \\
\text { As (4) }\end{array}$ & $\begin{array}{l}\text { (3) } \\
\text { As (7) }\end{array}$ \\
\hline TOURIST & $\begin{array}{l}\text { (4) } \\
\text { Telephone; Letter; } \\
\text { Internet feedback } \\
\text { sites; } \\
\text { Online guidebook } \\
\text { forums; } \\
\text { Communication with } \\
\text { holiday reps; } \\
\text { TV consumer } \\
\text { programmes }\end{array}$ & $\begin{array}{l}\text { (5) } \\
\text { Conversations; } \\
\text { Consultations; } \\
\text { Word-of-Web: } \\
\text { overheards; } \\
\text { confessions; blogs; e- } \\
\text { mails; word-of-mouth } \\
\text { accounts of } \\
\text { experiences; } \\
\text { Virtual } \\
\text { communities }\end{array}$ & $\begin{array}{l}\text { (6) } \\
\text { As (8) }\end{array}$ \\
\hline TOUREE & $\begin{array}{l}\text { (7) } \\
\text { Focus groups; } \\
\text { Local print media; } \\
\text { Local radio and TV } \\
\text { with responses; } \\
\text { A posteriori survey }\end{array}$ & $\begin{array}{l}\text { (8) } \\
\text { Home-stays; } \\
\text { Tribal TV; } \\
\text { Jungle tours; } \\
\text { Marginal people, } \\
\text { e.g., beachboys }\end{array}$ & $\begin{array}{l}\text { (9) } \\
\text { Children's essays; } \\
\text { Children's drawings }\end{array}$ \\
\hline
\end{tabular}

are often conducted between strangers (e.g., in an airport, on a plane). Here reciprocal anonymity, and occasionally common fear of flying or mutual love of alcohol, often encourages the uninhibited sharing of secrets, thereby possibly contributing to greater discourse validity than if the two parties are merely responding to researcher-driven items on a questionnaire. Finally, cell 5 comprises what have been called "virtual tourist communities" (Wang, Yu and Fesenmaier, 2002). As the name suggests, these are online tourist communities that serve the consumer needs for communication, information and entertainment, by supplying travel information, tips, transactions, relationships and even possible travel companions. Members are connected via the four basic needs of interests, relationships, fantasy and transaction. By way of summarising the foregoing analysis, Wang et al (2002: 416) conclude: it is clear, however, that because of the experiential nature of tourism, virtual tourism communities will provide a substantial foundation with which to foster communication among and between travelers and the industry.'
Cell 9, where tourees communicate among themselves, has received a certain amount of attention from scholars, especially in academic research into tourism's impact on destination communities. However, the focus tends to be behavioural rather than sociolinguistic. Rarer examples of the latter are Crick's (1989) study of schoolchildren's descriptions of tourist hippies in Kandy, Sri Lanka, and Gamradt's (1995) investigation of Jamaican students' drawings of visitors to that Caribbean island. Interestingly, both inquiries deal with young people, who can be considered more likely to provide responses of greater validity than their supposedly more sophisticated elders. "Out of the mouths of babes..."

Second, there are instances of external dialogue:

- Industry-tourist / tourist-industry: cells 2 and 4,

- Industry-touree / touree-industry: cells 3 and 7,

- Tourist-touree / touree-tourist: cells 6 and 8 .

As far as industry-tourist-industry dialogue is concerned, instead of content/semiotic analyses of the topdown monological discourse of such media as brochures 
and NTO catalogues, attention can now centre on the dialogical responses that the industry offers to the complaints of tourists. Such replies can be by letter, by phone or via digital communication. Since the first two channels are not normally accessible to the public, (except respectively via letters to the editors of newspapers or radio/ television call-in programmes), it is mainly through the Internet that such dialogue is in greatest evidence.

Verbal feedback by tourists to holiday tour representatives (reps) also allows an operator to identify instances of service failure with a view to correcting them. The previously mentioned TV consumer programmes additionally provide sectors of the tourism industry with the opportunity to respond to areas of tourist dissatisfaction in a live setting. However, there is an added risk here, in that the victim's poorly stated case on account of accompanying incoherent rage is often mediated by the programme presenter who is typically a journalist eloquently putting forward that side of the argument with the further hope of a newsworthy story.

Once tourist-industry communication is digital, the addressee becomes even more exposed, since the Internet has potentially a far wider audience than a local, regional, national, or even international television station or broadcaster such as the BBC or CNN. Yet those firms which do deal adequately with tourist complaints often witness increases in customer satisfaction, retention and loyalty (Tyrell and Woods, 2004: 183-184). Typically, bottom-up e-communication puts tourists in touch with operators, airlines, hotels, etc., via third party sites whose drop- down menus contain such options as compliment, complaint and comment. Depending on the sector, each of these components has a series of sub-aspects that can accommodate most grievances and areas of satisfaction. Thus Planet Feedback (2004) for instance, after identifying the relevant company, (e.g., Hilton hotels), used to allow selection from frequently encountered topics, (e.g., check-in, checkout, food service, front desk and housekeeping). However, while this sort of feedback was commendable, the agenda were still $a$ priori and not as dialogical as if they had been articulated by the customer in a posteriori terms.

Some tourist board Websites also provide potential opportunities for tourists to communicate with the industry, as do online guidebooks. The latter are highly sophisticated and thoroughly democratic. Indeed, almost a decade ago, Lonely Planet (2004), for example, (even then available in English, French, Spanish and Italian), allowed travellers to communicate via e-mails, letters and travel blogs. Its interactive Thorn Tree Forum was open to discussions of experiences, and the rating of accommodation and restaurants, etc., whose assessments could provide current appraisals long before the appearance of the next published edition of the printed guide bringing information that might well be out-of-date by the time it reached the bookstores. Indeed, these various types of communication were so comprehensive that they were classified by country and region. Potential travellers who had yet to visit a given destination could also post queries and receive answers from others who had recently been there or were actually in situ (e.g., news about the latest Maoist attacks in Nepal). As a matter of fact, these voices of experience might well have had greater accuracy than such alternative official sources as the Foreign and Commonwealth Office (UK) or State Department (USA).

Today, Lonely Planet (2011) with over 500 travel guides covering some 195 countries, (with downloadable pdf chapters), can boast that its Thorn Tree Forum is now "the oldest travel community on the Web". Its material is currently arranged in five broad categories or "branches": Departure Lounge (countries), Lobby (e.g., travel technology, travel on a shoestring, travellers with disabilities), Check in (all about LP, community FAQs, guidebook updates), Tree House (culture vultures, travel bloggers, women travellers), Sell, Swap and Meet Up (house sitting and swapping, travel companions). LP has the following words of encouragement for potential members of the forum: 'Join fellow travellers to exchange travel information, advice, hints and tips. Get help, get connected, get inspired and have your say. Our community guidelines and community FAQs will help you get started. When you're ready, sign in and start posting by choosing the right forum branch for you.' Seven years ago, competitor Rough Guides (2004), with similar offerings, even had a chat room discussing the merits and disadvantages of its own publications when compared with rival guidebooks. Possibly more high tech than LP, Rough Guides (2011) today claims to comprise some " $700+$ travel guides, e-books, apps, maps and phrasebooks", as also access to millions of digital photos. It has 200 travel destinations described as "ultimate travel experiences" and a corresponding eschatological sounding book entitled Make the Most of Your Time on Earth. It additionally carries other "life is for living" titles that are not necessarily travel related such as Babies and Toddlers, Conspiracy Theories, Future, Chick Flicks, Happiness, and Next Big Thing. Digital offerings include RG mobile, travel podcasts and e-books, as well as inevitable links to Twitter and Facebook. A similar facility for digital counselling can be found in the previously mentioned Trip Advisor which can sometimes give unprejudiced (?) reviews of tourist accommodation, transport, etc., with many money-saving tips. Often these reviews can be found on hotel websites that are included among the offerings of online travel agents such as Expedia and Travelocity.

Industry-touree dialogue is found in cells 7 and 3 . Now, where the monological accent was previously on imposing industry led concerns on host communities, there is currently extra scope for listening to the voices of destination residents. Here, instead of the old stimulus-response quantitative surveys, grounded theory qualitative issues can be tackled via an a posteriori approach that can be accommodated via ethnographic research and focus groups. One area that is particularly appropriate for this type of treatment is the self-imagery that destination people would like to project of themselves, their aspira- 
tions, goals and quality of life.

Turning to touree initiated dialogue, here the emphasis is also on destination people communicating with the industry. Usually the relative powerlessness of these residents means that they only do so indirectly, for instance, in local newspapers through letters to the editor, or via local radio call-in programmes. The authorities often reply to these voices of dissent in the same media (in the latter case they are typically asked to do so by the programme's moderator in order to achieve "balance"). Here the industry lets the aggrieved tourees know how fortunate they are in deriving the economic benefits of tourism in exchange for relatively lower social and cultural costs. Dann's (2004a) analysis of Barbadians' adverse reactions to their patronising portrayal in the American TV soap opera, The Bold and the Beautiful, is an instance of this comparatively rare genre. In this example, locals rightly object to their being allocated roles of primitive extras, as little more than pre-modern natives running around in grass skirts, living in rickety shacks and drawing water from a standpipe. However, and as they vociferously point out in one of the island's newspapers, the truth of the matter is that they have a far higher literacy rate than their US audience and are quite au fait with the latest technology. This type of communication, therefore, is a method of de-othering or self-image projection, what Hollinshead (1993) calls "dis-identification". Elsewhere, and perhaps more traditionally, such communication has been referred to as "resident responsive tourism" (Ritchie, 1993; Goeldner and Ritchie, 2009). Spanish speakers, on the other hand, tend to use the expression turismo comunitario (Ruiz-Ballesteros and Hernández-Ramirez, 2010), albeit conveying a similar meaning. However, in spite of its merits, there are some disadvantages, namely the tendency to treat local community involvement from a functionalist point of view, and hence as homogeneous and free from cultural constraint (Blackstock, 2005)

Tourist-touree dialogue (cells 8 and 6 ) is less frequently encountered since it is typically associated with the sharing of accommodation or some other host-tourist experience (e.g., dining) that previously, under a regime of mass tourism, was only undertaken with fellow tourists. Going under the name of "alternative tourism" (or one of its many forms), more so perhaps when home-stays are organised by the tourism industry (e.g., agro-tourism), here the emphasis is rather on direct tourist/host interaction. An interesting televised variant of such dialogue can be found in those quasi-anthropological programmes where intrepid, present-day explorers live with remote "natives" and share their broadcast experiences with a home-based audience. Such was the case of a six-part series put out by the British Broadcasting Corporation (2005) under the suitable caption "Tribe". The last of these episodes saw one Bruce Parry engaging with the Sanema people of Venezuela and other programmes witnessed him undergoing dangerous initiation rites and partaking of strange food. Where this type of offering differs from other reality TV shows, (e.g., I'm a Celebrity: Get Me out of Here,
Big Brother), is that the latter, focusing on pain suffered among equals, deliberately exclude locals.

Then there are those situations where tourees take the initiative in communicating with tourists. At the community level, they are exemplified by such "fair trade" practices as visitors shopping for souvenirs in Patan's Jawalakhel Handicraft Centre, thereby helping elderly and poor emigré Tibetans in Nepal (Reed, 2002: 164). They are likewise evident in Kathmandu's Ladybird Gift Shop retailing dolls and paper products in support of an organisation for girls at risk (Reed, 2002: 165). Toureetourist communication is also illustrated by locally organised jungle tours in Chiang Mai, Thailand (Cohen, 1989). Here the asymmetry of the discourse between tourists and indigenes has been analysed by Cohen and Cooper (1986). At the one-to-one individual level, host-guest dialogue is epitomised by tourist-beach boy encounters in Barbados, an interesting example of negotiated role reversal and corresponding imputation of motive (Karch and Dann, 1981). Like other instances of sex tourism also falling into this category, in beachboy tourism there is a dialogical trade-off between wealth (tourists) and knowledge (tourees) (van den Berghe, 1994). However, such communication is far from symmetrical, and is ultimately based on First World / Third World disparate power relationships (Karch / Dann, 1981).

\section{Model 3: The language of tourism as trialogue}

Finally, there is trialogue where three types of communication are envisaged according to the initiator of the discourse, but ultimately relying on self-reflexivity combined with the responses of the other two parties taken together. In some instances the direction of the dependency is reversed, as in the role switching between sender and addressee. Whatever the situation, however, it manages to unite internal and external communication into a three-way process. Hence a change in numeration from the previous two models.

The first case of trialogue is industry driven, the result of internal debate (need identification) and joint dialogue with tourists and tourees. An example (Cell 1) is a "meet the people" initiative. Jamaica, being one of the first places to introduce such a programme successfully, saw the Tourist Board (industry) persuading locals that it would be to their benefit to share their common interests with visitors. Tourists were similarly encouraged to interact with Jamaicans on an equal footing and soon "meet the people" became a regular feature of tours highlighted in overseas brochures (e.g., The Travel Collection, 2005). The experiment was also conducted, (some would say "begun"), on cruise-ships where families from upcoming Jamaican ports-of-call joined the cruise prior to the passengers' arrival, thereby familiarising the latter with what lay in store for them. There was also the hope that, as a result of this one-day "taster experience", cruise ship excursionists would at a later date return to the island in the role of more lucrative long stay visitors.

An instance of tourist-initiated trialogue (cell 2) is 
Table 3: The Language of Tourism as Trialogue

\begin{tabular}{|c|c|c|c|}
\hline & $\begin{array}{llll}\text { S } & \text { E } & N & D\end{array}$ & 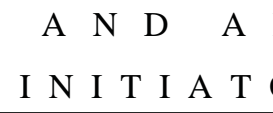 & $\begin{array}{lllllll}R & E & S & S & E & E\end{array}$ \\
\hline $\begin{array}{l}\text { SENDER AND } \\
\text { ADDRESSEE }\end{array}$ & INDUSTRY & TOURIST & TOUREE \\
\hline $\begin{array}{l}\text { INDUSTRY } \\
\text { TOURIST } \\
\text { TOUREE }\end{array}$ & $\begin{array}{l}\text { (1) } \\
\text { Meet the people }\end{array}$ & $\begin{array}{l}\text { (2) } \\
\text { Volunteer tourism }\end{array}$ & $\begin{array}{l}\text { (3) } \\
\text { Grass route tours; } \\
\text { Tsunami; } \\
\text { Community informatics }\end{array}$ \\
\hline
\end{tabular}

that variant known as "volunteer tourism" (Wearing, 2002). Here worthwhile Third World projects are identified and persons are encouraged to participate in them by paying their own way and helping disadvantaged others. Although most of these undertakings are non-touristic in nature, (often they are environmentally oriented), and all are located in developing countries, the act of joining in with local people as equals in a shared effort to improve indigenous lives (as well as those of the volunteers) can be considered touristic. For that reason, such "alternative tourism" is beneficial to the industry, particularly with the realisation that it tends to involve the more affluent type of patron.

Finally, there is touree-driven trialogue (cell 3) in which destination people send messages to the industry and tourists. Often they require assistance if their voices are to be fully heard and translated into action, as in the case of Grass Route Tours (2002) (sic) into the South African townships of Capetown, for instance. Another example of such trialogue was the Boxing Day tsunami of 2004, a disaster in which thousands of south-east Asians perished, leaving the survivors to address the outside world, (principally in English, the language of the BBC and $\mathrm{CNN}$ ). Although much of the devastated area had once been dedicated to tourism, attainment of the status quo ante would now take considerable time and funding to recover. However, and just as significantly by association, many of the coastal zones that had not been affected by the floods, were similarly adversely and inaccurately portrayed as those that had been ruined. In order to remedy the situation it was essential that factually accurate appraisals should be transmitted - ones that involved locals as well as visitors and the industry.

A final instance of this type of trialogue is community informatics, a form of self-representation over the Internet, as for instance in developing the Maori Heritage Trail (Kiwi-trails) with its own portal. The community level contact is accessed by a procedure known as "Web-raising", i.e., the community "working together to create a collective asset" (Milne, Mason, Speidel and West-Newman,
2005: 109) by sharing its skills with local businesses and thereby each party learning about one another. However, there are problems in such opening up to public gaze, including that of over-authenticity (e.g., showing the gory details of hunting, using the site as a place for religious conversion and inevitably allowing it to be overtaken by advertising (the case of Baffin island - (Milne (2006)). There are additionally difficulties in analysing community-based tourism if essentially functionalist models are being employed, along with the assumptions of homogeneity and cultural constraints to local control (Blackstock, 2005).

\section{Conclusion}

Although it can be a hazardous exercise to predict future trends in tourism and parallel developments in theory and method, a general attempt in this direction has already been undertaken in relation to Toffleresque, Simmelian and open-ended versions of reality (Dann, 1999). More specific examples provided here follow the latter approach in relation to one recent paradigm - that of tourism as language. However, while several scenarios of likely change have been outlined, along with their implicit potential in research, it should be evident that not every possibility has been envisaged by the three models. Nor has it been spelt out, other than by passing references to modifications in the surrounding social ethos, exactly how the transition is effected from monologue to dialogue and trialogue. Given limitations of space, that must constitute an area for further inquiry.

For the moment, though, if one takes an instance of traditional monological communication from the industry as sender to the tourist as addressee (Table 1, cell 4) - the package tour brochure - which still exists on account of its relative cheapness to produce and high conversion rate - does it mean that this type of print medium will continue in its present format when there have been alterations in other parallel media (e.g., the interactive nature of Web-based guidebooks, the transition from travelogue 
to travelblog)? In other words, why should there not be a respondent-friendly, interactive brochure that allows potential tourists to take virtual tours of resorts, listen to what previous visitors have to say about a given place and even perhaps include the voices of the destination people as to how they relish having outsiders in their midst? It is this last area where the least progress has been made, but it is surely one where, if the foregoing trends to dialogue and trialogue develop as outlined, one can expect the greatest transformation.

That said, it should be remembered that it is also possible that some of the old monological ways of tourism promotion may continue to be perpetuated on account of vested interests and lack of openness to change. Whereas a few enlightened sectors of the industry now see the advantages of adequately and publicly responding to their customers, there are still several die-hards who prefer to abstain. Apparently they do not see the need to reply to complaints at all, justifying their myopic position in terms of unnecessary expense (Tyrell and Woods, 2004: 184-185).

Thus there are two possible scenarios of the future development of "the language of tourism" - one denying change, the other promoting it. The former is pessimistic; the latter is optimistic. The first signifies even more control by the industry over those who gaze - tourists (Urry, 1990) and those who make a spectacle of themselves tourees (van den Berghe, 1994). The second means greater liberation for the visitor and the visited as they free themselves via resident-responsive tourism from the shackles of monological publicity to greater dialogical and trialogical employment of self-imagery.

Ontologically, these two positions are respectively rooted in the perennial tension between one and many. Epistemologically they are grounded in the a priori innate ideas of Plato or in the a posteriori, sensory-derived concepts of Aristotle (Dann, 2004b; (2008)). This article, if nothing else, should act as a constant reminder that the meanings structuring tourism as a facet of contemporary existence represent an ongoing struggle between these two dichotomous worldviews. However, they can only be fully revealed by stripping off the manifest content of messages of "the language of tourism" and by exposing their latent layers of connotation and the ideologies that underpin them.

\section{References}

Baudrillard, Jean

1983 Simulations. New York: Semiotext(e), Foreign Agent Press.

Blackstock, Kirsty

2005 A critical look at community based tourism. Community Development, 40(1): 39-49.

Brendon, Piers

1991 Thomas Cook: 150 years of popular tourism. London: Secker and Warburg.
British Broadcasting Corporation

2005 Tribe. BBC2 television, 3 January, 10 January, 17 January, 24 January, 31 January, 7 February.

Buhalis, Dimitrios and Law, Rob

2008 "Progress in tourism management: Twenty years on and 10 years after the Internet: the state of e-tourism research". Tourism Management 29(4): 609-623.

Channel 4 TV

2011 "Attack of the Trip Advisors". Cutting Edge, 31 October, 2100-2200.

Cohen, Erik

1989 "Primitive and remote: Hill tribe trekking in Thailand". Annals of Tourism Research 16(1): 30-61.

Cohen, Erik / Cooper, Robert

1986 "Language and tourism". Annals of Tourism Research 13(4): 533-563.

Complain Domain

2011 http://www.complaindomain.com (accessed 23 June; currently this site is unavailable).

Crick, Malcolm

1989 "The hippy in Sri Lanka: A symbolic analysis of the imagery of schoolchildren in Kandy". Criticism, Heresy and Interpretation 3: 37-54.

Cruises.co.uk

2011 http://www.cruises.co.uk (accessed 20 June)

Dann, Graham

1996 The language of tourism: a sociolinguistic perspective. Wallingford: $\mathrm{CAB}$ International.

Dann, Graham

1999 "Theoretical issues for tourism's future: Identifying the agenda". In Pearce, Douglas / Butler, Richard (Eds.), Contemporary issues in tourism development (pp.13-30). London: Routledge.

Dann, Graham

2001a "The language of tourism as monologue". Paper presented to the colloquium Worldscape 21: the communicative power of tourism, research committee on international tourism of the International Sociological Association, University of Liège, Belgium, 9-12 August.

Dann, Graham

2001b "Self-admitted use of cliché in the language of tourism". Tourism, Culture and Communication 3(1): $1-14$.

Dann, Graham

2003 "Noticing notices: tourism to order". Annals of Tourism Research 30(2): 465-484.

Dann, Graham

2004a (Mis)-representing the other in the language of tourism. Journal of Eastern Caribbean Studies 29(2): 76-94.

Dann, Graham

2004b "What Aristotle might have asked the future Alexander the Great on Mytilini: Is there anything new in tourism theory?" In Proceedings of the symposium on Understanding tourism-theoretical advances, University of the Aegean, Lesvos, Greece, 14-16 May 2004, (Published on CD-ROM, University of the Ae- 
gean, August 2004). Also subsequently published with permission in: 2008 "O co mógłby zapytać Arystotelesa przyszły Aleksander Wielki na wyspie Lesbos? 'Czy pojawiło się cos mowego w teorii turystyki?"'. Nowe Problemy Turystyki 1(1): 83-105. (Simultaneously published in English as What the future Alexander the Great might have asked Aristotle on Lesvos: 'Is there anything new in tourism theory?' New Problems of Tourism 1(1): 77-98.

Dann, Graham

2007 "Revisiting the language of tourism: what tourists and tourees are saying”. In De Stasio, Clotilde / Palusci, Oriana. (Eds.), The languages of tourism: turismo e mediazione (pp. 15-31). Milano: Edizioni Unicopli.

Dann, Graham

2009 "The language of tourism: Crises of credibility". Keynote address to the conference Communicare la città: il turismo culturale a Brescia in una prospettiva inter / nazionale, (Communicating the city: an international perspective on cultural tourism in Brescia), Università Cattolica del Sacro Cuore, Sede di Brescia, Centro Studi sul Turismo, 19-20 November.

Dann, Graham, / Liebman Parrinello, Giuli

2007 "Od putopisa do 'putobloga': redefiniranje identiteta turista (From travelog to travelblog: (re)-negotiating

tourist identity". Acta Turistica 19: 7-29.

Dann, Graham / Nash, Dennison / Pearce, Philip

1988 "Methodology in tourism research". Annals of Tourism Research 15: 1-28.

Denzin, Norman

1986 "Postmodern social theory". Sociological Theory 4(2): 194-204.

Fjellman, Stephen

1992 Vinyl leaves: Walt Disney World and America. Boulder, CO: Westview Press.

Gamradt, Jan

1995 "Jamaican children's representations of tourism". Annals of Tourism Research 22: 735-762.

Goeldner, Charles / Ritchie, J. R. Brent

2009 Tourism: principles, practices, philosophies. $11^{\text {th }}$ ed. Hoboken (NJ): Wiley.

Grass Route Tours

2002 Grass route tours (pamphlet). Cape Town: np.

Holiday Complaints

2011 http://www.holidaycomplaints.com (accessed 23 June).

Holiday Travel Watch

2011 http://www.holidaytravelwatch.net/ (accessed 23 June).

Hollinshead, Keith

1993 The truth about Texas. Unpublished $\mathrm{PhD}$ thesis, Texas A \& M University, USA.

Hollinshead, Keith / Jamal, Tazim

2001 "Delving into discourse: excavating the in-built power-logic(s) of tourism". Tourism Analysis 6(1): 63-73.

I GoUGo

2011 http://www.IgoUgo.com (accessed 23 June).

Karch, Cecilia / Dann, Graham
1981 "Close encounters of the Third World". Human Relations 34(4): 249-268.

Kilroy, Roger

1983 Graffiti 4: the empire writes back. London: Corgi Books.

Lee, Charles Changuk / Hu, Clark

2004 "Analyzing hotel customers' e-complaints from an Internet complaint forum". Journal of Travel and Tourism Marketing 17 (2/3): 167-181.

Lonely Planet

2004 http://www.lonelyplanet.com (accessed 25 October). 2011 http://www.lonelyplanet.com (accessed 17 June).

Lyotard, Jean

(1979) 1984 The postmodern condition: a report on knowledge. Minneapolis: University of Minnesota Press.

MacCannell, Dean

1992 Empty meeting grounds: the tourist papers. London: Routledge.

Mayo, Edward / Jarvis, Lance

1981 The psychology of leisure travel. Effective marketing and selling of travel services. Boston: CBI.

Milne, Simon / Mason, David / Speidel, Ulrich / WestNewman, Tim

2005 "Tourism and community informatics: the case of $\mathrm{Ki}$ witrails". Tourism, Culture and Communication 5(2): 105-114.

Milne, Simon

2006 "Baffin Island, Nunavut, Canada". In Baldacchino, G., (Ed.), Extreme tourism: lessons from the world's cold water islands (pp. 88-99). Oxford: Elsevier.

Minghetti, Valeria / Buhalis, Dimitrios

2010 "Digital divide and tourism: bridging the gap between markets and destinations". Journal of Travel Research XX(X): 1-15.

Morgan, Nigel / Pritchard, Annette

2000 Advertising in tourism and leisure. Oxford: Butterworth-Heinemann.

My Trip Journal

2011 http://www.mytripjournal.com (accessed 23 June).

Planet Feedback

2004 http://www.planetfeedback.com (accessed 25 October)

2011 http://www.planetfeedback.com (accessed 26 November).

Reed, David

2002 The rough guide to Nepal, $5^{\text {th }}$ ed. London: Rough Guides.

Ritchie, J. R. Brent

1993 "Crafting a destination vision: putting the concept of resident responsive tourism into practice". Tourism Management 14(5): 379-389.

Ritzer, George

1993 The McDonaldization of society. Newbury Park (CA): Pine Forge Press.

Rough Guides

2004 http://roughguides.atinfopop.com (accessed 25 October).

2011 http://www.roughguides.com (accessed 17 June). 
Ruiz-Ballesteros, Esteban / Hernández-Ramirez, Macarena

2010 "Tourism that empowers? Commodification and appropriation in Ecuador's turismo comunitario". Critique of Anthropology 30(2): 201-229.

Schoefer, Klaus / Ennew, Christine

2004 "Customer evaluation of tour operators' responses to their complaints". Journal of Travel and Tourism Marketing 17(1): 83-92.

Shea, Linda / Enghagen, Linda / Khullar, Ashish

2004 "Internet diffusion of an e-complaint: a content analysis of unsolicited responses". Journal of Travel and Tourism Marketing 17 (2/3): 144-165.

The Travel Collection

2005 "O island in the sun (travel advertisement on Jamaica)". Sunday Telegraph Magazine, 23 January: 52.

Travel Pod

12011 http://www.travelpod.com (accessed 23 June).

Tyrell, Brian / Woods, Robert

2004 "E-complaints: lessons to be learned from the service recovery literature". Journal of Travel and Tourism Marketing 17 (2/3): 183-190.

Urry, John

1990 The tourist gaze. Leisure and travel in contemporary societies. London: Sage.

Van den Berghe, Pierre

1994 The quest for the other. Ethnic tourism in San Cristóbal, Mexico. Seattle: University of Washington Press.

Wang, Ning

2000 Tourism and modernity: a sociological analysis. Oxford: Pergamon.

Wang, Youcheng / Yu, Quaehee / Fesenmaier, Daniel

2002 "Defining the virtual tourist community: implications for tourism marketing". Tourism Management 23: 407-417.

Wearing, Stephen

2002 "Recentring the self in volunteer tourism". In Dann, Graham (Ed.), The tourist as a metaphor of the social world (pp.237-262). Wallingford: CAB International.

Weiermair, Klaus / Fuchs, Matthias

1999 "Measuring tourist judgment on service quality". Annals of Tourism Research 26: 1004-1021.

\section{Notes}

1 Substantially revised version of a paper presented to the International Academy for the Study of Tourism, Beijing, June 30-July 5, 2005. The original version "Remodelling the language of tourism: From monologue to dialogue and trialogue" is due to be published in William Gartner and Cathy Hsu (eds.), Routledge Handbook of Tourism Research. London: Routledge (March 2012) and permission for Pasos to publish the updated version "Re-modelling a changing language of tourism: From monologue to dialogue and trialogue" has already been granted. Conversely should the special issue of Pasos appear before the Routledge publication then permission from Pasos is granted to Routledge to produce the earlier version.
Recibido:

$14 / 11 / 2011$

Reenviado:

$4 / 12 / 2011$

Aceptado:

$10 / 1 / 2012$

Sometido a evaluación por pares anónimos 